\title{
STUDIES OF EFFECTS OF $t$-ALLELES IN THE HOUSE MOUSE ON SPERMATOZOA
}

\author{
II. QUASI-STERILITY GAUSED BY DIFFERENT \\ COMBINATIONS OF ALLELES
}

\author{
L. G. DUNN AND DOROTHEA BENNETT \\ Nevis Biological Station, Columbia University, Irvington, New York and \\ Department of Anatomy, Cornell University Medical College, New York, N.r.
}

(Received 22nd August 1968)

\begin{abstract}
Summary. Mating tests of males bearing different combinations of alleles near locus $T$ show fertility differences from near sterile to near normal fertility depending on the specific alleles combined. Viable $t$-alleles with no marked effects on fertility when homozygous, fall into different fertility categories when each is combined with the same lethal allele. The differences are attributed to effects on sperm function exerted by the properties of an important controlling centre in the ninth linkage group.
\end{abstract}

\section{INTRODUCTION}

A recent communication (Bennett \& Dunn, 1967) reported on studies of spermatozoa from mice having certain combinations of alleles at locus $T$ (linkage group IX) which rendered them entirely mating-sterile. One form of genotypic sterility in males with a combination of two lethal $t$-alleles or of one lethal and one semi-lethal, was correlated not with reduced numbers of spermatozoa ejaculated but with reduced motility. The semi-lethal allele was originally referred to as a 'wild-viable' allele (Bennett \& Dunn, 1967). It has since been observed that sterile males homozygous or compound for semi-lethal alleles from wild populations $\left(t^{w 2}, t^{w 8}, t^{w 36}\right)$ have virtually no spermatozoa at all in their ejaculates. Details of this finding will be reported in a subsequent paper. It is already clear that the causes of sterility differ sharply in the two cases even though both are associated with combinations of closely related and adjacent mutations.

This report concerns the 'quasi-sterility' associated with certain combinations of viable and lethal $t$-alleles. The eventual question concerning these is by what means are major proportions of the total sperm output prevented from accomplishing normal fertilization. The immediate questions concern the identification and classification of those genotypes which are associated with quasi-sterility, and the definition and genetic analysis of this phenomenon. 
Quasi-sterility

This form of impairment of male fertility was first noted when males carrying a viable and a lethal $t$-allele $t^{3} / t^{1}, t^{3} / t^{0}$ were tested (Dunn \& GluecksohnWaelsch, 1951). Most males of these genotypes proved to be mating-sterile (see below for definitions). Of those that produced some offspring, all showed less than normal fertility and most showed less than $20 \%$ of normal fertility. These were referred to as quasi-sterile. The occurrence of males of a multiparous mammal with a reduced fertility was surprising especially as it was not associated with loss of conceptuses before birth and occurred in the presence of great numbers of apparently normal spermatozoa (Dunn, 1952). It suggested that some minimum quantum of spermatozoa (probably a large number) might be required for each fertilization.

Braden \& Gluecksohn-Waelsch (1958) tested the fertility and examined the spermatozoa of males with different combinations of $t$-alleles. Some of these were mating-sterile, others quasi-sterile and a few showed normal fertility. An important feature of their findings was that males with one viable and one lethal $t$-allele were, in general, highly infertile or quasi-sterile, yet produced normal numbers of spermatozoa. Spermatozoa of all genotypes examined showed some abnormal forms but the frequency of these was not correlated with fertility status.

Rajasekarasetty (1951) also failed to find a correlation between the proportion of abnormal spermatozoa and the degree of sterility in quasi-sterile males with a lethal and a viable $t$-allele and presumed that the normal spermatozoa, which were in the great majority, were 'physiologically inefficient'.

Quasi-sterility has now been observed in males of many different genotypes involving combinations of a lethal, or semi-lethal, with ai viable $t$-allele $\left(t^{t} / t^{v}\right)$. Viable $t$-alleles, which have arisen in independent events of what was at first thought to be mutation and is now known to be due to exceptional recombination, usually produce little or no impairment of fertility in homozygous males $\left(t^{v} / t^{v}\right)$. In combination with a given lethal, certain viable alleles appeared not to affect male fertility at all while others produced sterility or quasi-sterility. This seemed to offer a means of discriminating between independently arisen viable alleles, which were indistinguishable in their effects on tail development, viability and recombination. The identification of a certain fertility level with a certain $t$-allele (in $t^{t} / t^{v}$ combinations) would provide a genotypic means of control by which males with different degrees of fertility could be regularly obtained for study.

\section{METHODS}

An early experiment in which interaction between a lethal and viable $t$-allele produced impaired fertility in male $t^{l} / t^{v}$ mice illustrates the methods used in studying such cases. A list and description of the $t$-variants used will be found in the paper of Dunn, Bennett \& Beasley (1962). The two alleles were $t^{w 1}$, a lethal, in which homozygotes die in the latter half of the gestation period; and $t^{13}$ in which homozygotes have normal viability until birth and can become adults. Male homozygotes $t^{13} / t^{13}$ are known to be fertile, although quantitative 
studies of their fertility were not made. Matings of $T / t^{w 1}$ and $T / t^{13}$ (each from balanced tailless lines) were made reciprocally. From these crosses, normal-tailed $t^{w 1} / t^{13}$ mice appeared in the expected proportions at birth, showing that this genotype has normal viability at birth. Thirty-three such males were tested for relative fertility by mating each with Brachy, i.e. shorttailed females of genotype $T /+$. A pool of such females was established, each of which had had at least one litter of five or more, and these were rotated through the pens in which the $t^{w 1} / t^{13}$ males were under test. Females were removed from such pens when pregnant and replaced by a fertile female from the pool. Each 4 weeks of exposure of a male to a fertile female was counted as one 'mating unit'. Ten mating units constituted the minimum test of mating fertility of a male, and a male which failed to sire any offspring after such a test was recorded as 'mating sterile'.

Table 1 shows the results of two control experiments designed to establish standards for classifying males for relative fertility. The first line shows that seventeen Brachy males tested by Brachy females from the stock which provided

TABLE 1

COMPARISON OF FERTILITY OF MALES CARRYING A LETHAL AND A VIABLE $t$-ALLELE WITH TWO SETS OF CONTROL MALES

\begin{tabular}{|c|c|c|c|c|c|c|}
\hline Males tested & $\begin{array}{c}\text { Total } \\
\text { offspring }\end{array}$ & $\begin{array}{c}\text { Total } \\
\text { mating } \\
\text { units }\end{array}$ & $\begin{array}{c}\text { Matin } \\
\text { offspring } \\
\text { Average }\end{array}$ & $\begin{array}{l}\text { fertility } \\
\text { nating unit } \\
\quad \text { Range }\end{array}$ & $\begin{array}{c}\text { Average fertility } \\
\quad(\text { standard } \\
=5 / \text { mating unit })\end{array}$ & $\begin{array}{c}\text { Average } \\
\text { litter } \\
\text { size }\end{array}$ \\
\hline \multirow{2}{*}{$\begin{array}{l}17 T /+ \text { (controls) } \\
4+/ t^{13} \text { and }+/ t^{w 1} \\
\quad \text { (controls) } \\
33 t^{w 1} / t^{13}\end{array}$} & $924 *$ & 195 & $4 \cdot 7$ & 3.0 to 6.0 & 100 & $7 \cdot 8$ \\
\hline & $\begin{array}{l}285 \\
712\end{array}$ & $\begin{array}{r}56 \\
642\end{array}$ & $\begin{array}{l}5 \cdot 1 \\
1 \cdot 1\end{array}$ & $\begin{array}{l}3.9 \text { to } 7 \cdot 2 \\
0.0 \text { to } 3 \cdot 0\end{array}$ & $\begin{array}{r}100 \\
22\end{array}$ & $\begin{array}{l}6 \cdot 8 \\
3 \cdot 3\end{array}$ \\
\hline
\end{tabular}

* Actual count at birth was 739 ; but since the test females were also $T /+$ and all $T / T$ zygotes $(1 / 4$ of all zygotes) are known to die during gestation, the birth count has been increased by $25 \%$.

the pool of fertile females gave about five offspring (actually $4 \cdot 7$ ) per mating unit, and an average litter size of about eight. In the second line are shown tests of males carrying one of the $t$-alleles to be tested. These also gave about five offspring per mating unit and litter sizes of about seven. It therefore seems safe to accept five offspring per mating unit as standard for the stocks used and to regard this as 100 on a relative fertility scale. The third line of Table 1 shows that, when similarly tested, thirty-three males with both $t$-alleles, $t^{w 1}$ and $t^{13}$, had, on average, a mating fertility that was only about $20 \%$ of that of the control males and a litter size about half as large. There is thus clear evidence that the two $t$-alleles, neither of which gives noticeable impairment of fertility when combined with a normal or Brachy allele, will interact in the zygote to reduce the fertility of this genotype. No impairment of fertility in females of this genotype, $t^{l} / t^{v}$, has been noted.

Table 2 shows the performance of these thirty-three $t^{w 1} / t^{13}$ males in more detail. None achieved a fertility higher than $60 \%$ of the standard value. Half showed fertilities less than $20 \%$ of standard. The latter was the level chosen in previous work (Dunn, 1952) to designate quasi-sterility. This, like other 
fertility classifications, represents an arbitrary interruption of an essentially continuous distribution. These effects, it should be emphasized, have been expressed in terms of sperm function (success in fertilization) relative to the spermatozoa of males having one Brachy and one normal allele $(T /+)$ when functioning in the reproductive tracts of $T /+$ females. The latter is the standard chosen, and the behaviour of other genotypes, such as $t^{w 1} / t^{13}$ in the example above, is expressed in proportions of the standard genotype $T /+$, and not in terms of some hypothetical 'normal' value.

TABLE 2

CLASSIFICATION OF THIRTY-THREE MALES OF GENOTYPE $t^{w 1} / t^{13}$ BY MATING FERTILITY AND RELATIVE FERTILITY

\begin{tabular}{|c|c|c|c|}
\hline No. of males & $\begin{array}{c}\text { Mating fertility } \\
\text { (offspring/mating unit) }\end{array}$ & $\begin{array}{l}\text { Relative fertility } \\
\% \% \text { of standard } \\
\text { (5/mating unit) }\end{array}$ & Class \\
\hline $\begin{array}{l}4 \\
6 \\
6 \\
9 \\
1 \\
5 \\
2\end{array}$ & $\begin{array}{l}0 \\
0.01-0.49 \\
0.50-0.99 \\
1 \cdot 00-1.49 \\
1.50-1.99 \\
2 \cdot 00-2.49 \\
2 \cdot 50-2.99\end{array}$ & $\begin{array}{l}0 \\
1-9 \\
10-19 \\
20-29 \\
30-39 \\
40-49 \\
50-60\end{array}$ & $\begin{array}{l}\text { Mating sterile } \\
\text { Quasi-sterile } \\
\text { Quasi-sterile } \\
\text { Low fertility } \\
\text { Low fertility } \\
\text { Reduced fertility } \\
\text { Reduced fertility }\end{array}$ \\
\hline
\end{tabular}

TABLE 3

RESULTS OF FERTILITY TESTS OF $t^{w 12} / t^{n}$ MALES

\begin{tabular}{|c|c|c|c|c|c|}
\hline $\begin{array}{l}\text { Genotype } \\
\text { of males }\end{array}$ & $\begin{array}{l}\text { No. of males } \\
\text { tested }\end{array}$ & $\begin{array}{c}\text { No. with } \\
\text { no } \\
\text { offspring }\end{array}$ & $\begin{array}{c}\text { Noo. } \\
\text { quasi- } \\
\text { sterile }\end{array}$ & $\begin{array}{c}\text { Mating fertility } \\
\text { (offspring/mating unit) }\end{array}$ & $\begin{array}{l}\text { Relative fertility } \\
\% \text { of standard } \\
(=5 / \text { mating unit })\end{array}$ \\
\hline $\begin{array}{l}t^{w 12} / t^{26} \\
t^{w 12} / t^{27} \\
t^{w 12} / t^{28} \\
t^{w 12} / t^{w 29} \\
t^{w 12} / t^{w 31}\end{array}$ & $\begin{array}{l}5 \\
6 \\
5 \\
4 \\
6\end{array}$ & $\begin{array}{l}4 \\
4 \\
4 \\
4 \\
4\end{array}$ & $\begin{array}{l}1 \\
2 \\
1 \\
2\end{array}$ & $\begin{array}{l}1 / 50=0.02 \\
8 / 64=0.13 \\
2 / 50=0.04 \\
0 / 43=0.00 \\
7 / 62=0.11\end{array}$ & $\begin{array}{l}0.4 \\
2.6 \\
0.8 \\
0.0 \\
2 \cdot 2\end{array}$ \\
\hline
\end{tabular}

\section{RESULTS}

Following the test of methods in the preliminary experiment, the effect upon male fertility of each of a series of viable $t$-alleles was tested by combining each with the same lethal, $t^{w 12}$, which is indistinguishable from the $t^{w 1}$ used above.

Table 3 shows the result of this test. It was apparent that fertility in all of the combinations tested was so low as to provide no prospect of distinguishing between the viable alleles by using $t^{w 12}$. The few males that showed any fertility were all low grade quasi-steriles.

Another $t$-lethal allele, $t^{0}$, was therefore used. Compounds of $t^{0}$ were made up with each of eight $t$-viable alleles, including the five shown in Table 3. Of the eight alleles, seven had been tested for fertility effects in homozygous males. All such males were fertile, though two showed somewhat reduced fertility. The results of testing the males are shown in Table 4. In general, the $t^{\circ}$ com- 
binations showed much greater fertility than those with $t^{w 1}$. In spite of considerable variation in fertility between males of the same $t$-genotype, some consistent differences among the viable alleles were in evidence. Most of the males with $t^{0}$ and $t^{38}$ showed normal fertility, with relative fertility scores of $132,109,98,85,68,65 \%$. One was low (35) and one was quasi-sterile (11). All gave litters of normal size. Those with $t^{\circ}$ and $t^{w 31}$ showed a similar range and litter size. The $t^{0} / t^{w 33}$ males were somewhat less fertile but none was sterile or quasi-sterile.

TABLE 4

RESULTS OF MATING FERTILITY TESTS OF $t^{l} / t^{v}$ MALES

\begin{tabular}{|c|c|c|c|c|c|c|c|}
\hline $\begin{array}{l}\text { Genotype } \\
\text { of males }\end{array}$ & $\begin{array}{c}\text { No. of males } \\
\text { tested }\end{array}$ & $\begin{array}{c}\text { No. with } \\
\text { no } \\
\text { offspring }\end{array}$ & $\begin{array}{c}\text { No. } \\
\text { quasi- } \\
\text { sterile }\end{array}$ & $\begin{array}{c}\text { Mating fertility } \\
\text { (offspring/mating unit) }\end{array}$ & $\begin{array}{l}\text { Relative fertility } \\
\% \text { of standard } \\
(=5 / \text { mating unit })\end{array}$ & $\begin{array}{l}\text { Offs } \\
\text { Quasi- } \\
\text { sterile }\end{array}$ & $\begin{array}{l}\text { pring/litter } \\
\text { Above quasi- } \\
\text { sterile }\end{array}$ \\
\hline $\begin{array}{l}t^{0} / t^{26} \\
t^{0} / t^{27} \\
t^{0} / t^{28} \\
t^{0} / t^{29} \\
t^{0} / t^{38} \\
t^{0} / t^{w 29} \\
t^{0} / t^{w 31} \\
t^{0} / t^{w 33} \\
t^{w 2} / t^{38} \\
t^{w 8} / t^{38} \\
t^{w 1} / t^{13}\end{array}$ & $\begin{array}{r}11 \\
7 \\
4 \\
8 \\
8 \\
10 \\
8 \\
4 \\
10 \\
5 \\
33\end{array}$ & $\begin{array}{l}4 \\
3 \\
2 \\
2 \\
7 \\
- \\
1 \\
1 \\
4\end{array}$ & $\begin{array}{r}4 \\
3 \\
2 \\
3 \\
1 \\
3 \\
\\
2 \\
2 \\
12\end{array}$ & $\begin{aligned} 95 / 162 & =0.59 \\
59 / 117 & =0.50 \\
4 / 74 & =0.05 \\
121 / 150 & =0.81 \\
570 / 150 & =3.80 \\
12 / 119 & =0.10 \\
423 / 128 & =3.31 \\
117 / 65 & =1.80 \\
329 / 203 & =1.62 \\
196 / 100 & =1.96 \\
712 / 642 & =1 \cdot 11\end{aligned}$ & $\begin{array}{l}12 \\
10 \\
1 \cdot 0 \\
16 \\
76 \\
2 \cdot 0 \\
66 \\
36 \\
32 \\
40 \\
22\end{array}$ & $\begin{array}{l}3 \cdot 5 \\
2 \cdot 9 \\
2 \cdot 0 \\
4 \cdot 2 \\
4 \cdot 0 \\
2 \cdot 4 \\
- \\
2 \cdot 0 \\
5 \cdot 7 \\
3 \cdot 0\end{array}$ & $\begin{array}{l}-\overline{6} \\
5 \cdot 3 \\
6 \cdot 8 \\
-5 \cdot 2 \\
5 \cdot 0 \\
6 \cdot 4 \\
8 \cdot 9 \\
-\end{array}$ \\
\hline
\end{tabular}

TABLE 5

FERTILITY EFFECTS ON MALES CARRYING THE VIABLE $t$-ALLELES WHEN THESE ARE COMBINED WITH THE LETHAL $t^{0}$

\begin{tabular}{l|c|c|c|c}
\hline & $\begin{array}{c}\% \\
\text { mating } \\
\text { sterile }\end{array}$ & $\begin{array}{c}\% \\
\text { quasi- } \\
\text { sterile }\end{array}$ & $\begin{array}{c}\text { Offspring } \\
\text { quasi- } \\
\text { sterile }\end{array}$ & $\begin{array}{c}\text { Litter } \\
\text { above quasi- } \\
\text { sterile }\end{array}$ \\
\hline Near normal: $t^{\mathbf{2 1}}, t^{\mathbf{w 3 3}}, \mathbf{t}^{\mathbf{3 8}}$ & 0 & 5 & $4 \cdot 0$ & $6 \cdot 8$ \\
Below normal: $t^{\mathbf{2 6}}, t^{\mathbf{2 7}}, t^{29}$ & 35 & 38 & $3 \cdot 5$ & $5 \cdot 5$ \\
Near sterile: $t^{\mathbf{2 8}}, t^{\mathbf{2 2 9}}$ & 65 & 35 & $2 \cdot 3$ & - \\
\hline
\end{tabular}

A rather crude classification of all $t^{0} / t^{v}$ males tested is given in Table 5. This shows that not all $t$-viable alleles are alike in their effects on male fertility. The three categories in Table 5 differ most sharply in the proportions of completely sterile males. Litter size as well as frequency of litters is reduced in quasisterile males, as is shown also in Table 4. This reduction is greatest in males of lowest fertility.

It does not seem possible to determine how many kinds of $t$-viable alleles are represented in the present sample. The chief difficulty is that males of the same genotype respond to the test procedures in widely different ways. Uncontrolled variables which may contribute to this are genotypic heterogeneity at loci other than $t$ and physiological state and cyclical variation in both males and females. The classification of $t$-viable alleles by complementation tests with 
other $t$-alleles using male fertility as the criterion will have to await more rigorous methods of testing fertility. In the meantime, it is evident that many combinations may produce quasi-sterility and that ample test material is thus made available.

Having compared several viable $t$-alleles combined with the same lethal allele, tests were made of one viable allele, $t^{38}$, combined with a lethal and with each of two semi-lethal alleles. The results are shown in Table 4 . The effect on male fertility of the semi-lethals $\left(t^{\omega 2}\right.$ and $\left.t^{w 8}\right)$ appeared to be more severe than that of the lethal $\left(t^{0}\right)$. The $t^{0} / t^{38}$ males had nearly normal fertility, while the $t^{w 2} / t^{38}$, and $t^{w 8} / t^{38}$ males were quite similar but as a group had much lower fertility than $t^{0} / t^{38}$. Of the latter group of males, two out of fifteen or $13 \%$ were mating-sterile, and four of fifteen or $27 \%$ were quasi-sterile as compared with $0 \%$ and $12 \%$, respectively, for $t^{\circ} / t^{38}$.

The last line of Table 4 records comparable data for $t^{w 1} / t^{13}$ males which showed $12 \%$ mating sterile and $36 \%$ quasi-sterile.

The data produce the impression that some $t$-alleles, which by themselves show little or no effect on male fertility, do nevertheless exert, in other combinations, a significant influence on the fertility of males. This, like the effect of $t$-alleles in producing taillessness in combination with the allele $\mathcal{T}$, is probably one of the commonest properties of mutants at this locus.

\section{DISGUSSION}

A main feature of the experiments reported here is the interference with sperm function which regularly accompanies the joint action of specific mutant alleles. The more or less continuous nature of the variations in the degree of fertility clearly shows that sperm function is affected not only by the genetic factors identified as $t$-alleles but probably by other genotypic and non-genetic variables as well. The levels of fertility, such as quasi-sterility, which may be recognized by mating tests, are thus arbitrary divisions made for convenience, and are simply descriptions of the outcomes of operative procedures. The important questions concern the biological meaning of this kind of fertility control in the male.

The manner in which control is exercised can be discussed by events at three different levels: first, that of gene interaction; second, that of phenotype differences expressed in sperm number, morphology and function; and third, that of the adaptive significance of such a control system in natural populations.

The results of the present work, of Dunn (1952) and of Braden \& Gluecksohn-Waelsch (1958) agree in showing that the male fertility grade is jointly affected by a $t$-allele derived from the mother and by one from the father. The $t$-genotype of the zygote is thus a chief factor and the alleles may be viewed as interacting in the diploid cells leading to or surrounding the haploid cells which produce the spermatozoa. The nature of this interaction is not clear, but it is known that 'transmission ratio distortion', another effect on sperm behaviour controlled within this same region (Dunn, 1964), is not involved. Males which are heterozygous for a lethal (or semi-lethal) allele and a normal allele generally transmit the lethal to a preponderance of their offspring in ratios characteristic 
of the particular alleles. For example, $t^{w 1}$ and $t^{\omega 2}$ have high ratios, above $90 \%$, while $t^{0}$ shows about $80 \%$ transmission. Conversely, different viable $t$-alleles are characterized by ratios which are low or normal. The degrees of ratio distortion of alleles combined in a $t^{l} \mid t^{v}$ male, however, do not show any correlation with the fertility effect of this combination. In Table 5, for example, two of the three viable alleles showing near normal fertility with $t^{0}$ have normal transmission ratios while one $\left(t^{38}\right)$ has a low ratio; the same is true of the below normal category (two normal, one low) and of the near sterile class (one normal, one low). Other types of interaction between alleles with different transmission ratios will be discussed in a subsequent paper.

The interaction of two alleles which leads to quasi-sterility is expressed in two gross effects. Litters from such males are less frequent and smaller in size (fewer offspring per litter at birth). The reduction in litter size is not due to prenatal loss of conceptuses (Gluecksohn-Schoenheimer, Segal \& Fitch, 1950). There is also a rough correlation between fertility grade and both litter size and litter frequency. Both effects on decreasing fertility are probably due to failure of increasing proportions of spermatozoa to penetrate the eggs. Rajasekarasetty (1951) and Braden \& Gluecksohn-Waelsch (1958) observed that in quasisterile males the quantity of spermatozoa ejaculated is not markedly reduced, nor is the proportion of abnormal spermatozoa greatly increased.

Although it is apparent that certain lethal alleles, such as $t^{w 12}$ (Table 3), have much more drastic effects on fertility than others, such as $t^{0}$ (Table 4), even when combined with the same $t$-viable alleles, there is no information on the means by which such effects occur and they deserve further study.

The frequent association of fertility effects with alleles in one region of one chromosome shows that an important controlling centre is located there. Some of these alleles may be regarded as iso-alleles in the sense that they exert no noticeable effects on fertility except when in combination with other alleles in this region. Some of these variant alleles are found in wild (feral) house mouse populations as rather common polymorphisms, suggesting that the chromosome region in which they occur has important adaptive potentialities, of which fertility control is one.

\section{ACKNOWLEDGMENTS}

One of us (L.C.D.) wishes to acknowledge the support of the U.S. Atomic Energy Commission Contract AT(30-1) 1804. D.B. is a Career Investigator of the Health Research Council of the City of New York and wishes to acknowledge the support of USPHS Grant 9912.

\section{REFERENCES}

Bennett, D. \& Dunn, L. C. (1967) Studies of effects of $t$-alleles in the house mouse on spermatozoa. I. Male sterility effects. 7. Reprod. Fert. 13, 421 .

Braden, A. W. H. \& Gluecksohn-Waelsch, S. (1958) Further studies of the effect of the T-locus in the house mouse on male fertility. F. $\exp$. Zool. 138, 431.

Duns, L. C. (1952) Genetically determined variation in male fertility in the house mouse. In: Studies on Testis and Ovary, Eggs and Sperm, p. 217. Ed. E. T. Engle. Thomas, Springfield, Illinois.

DunN, L. C. (1964) Abnormalities associated with a chromosome region in the mouse. Science, N.Y. 144, 260. 
Dunn, L. C., BennetT, D. \& BeAsley, A. B. (1962) Mutation and recombination in the vicinity of a complex gene. Genetics, Princeton, 47, 285.

Dunn, L. C. \& Gluecksohn-WaEtsch, S. (1951) On the origin and genetic behaviour of a new mutation $\left(t^{3}\right)$ at a mutable locus in the mouse. Genetics, Princeton, 30, 4.

Gluecksohn-Schoenheimer, S., Segal, R. \& Fitch, N. (1950) Embryological tests of genetic male sterility in the house mouse. 7. exp. Zool. 113, 621.

RAJASEKARASETTY, M. R. (1951) Relation of sperm morphology to genotypically controlled variations in fertility. Proc. Soc. exp. Biol. Med. 78, 845. 